\title{
AMPK as a mediator of hormonal signalling
}

\author{
Chung Thong Lim, Blerina Kola and Márta Korbonits \\ Endocrinology, Barts and the London School of Medicine and Dentistry, William Harvey Research Institute, Queen Mary University of London, Charterhouse Square, \\ London EC1M 6BQ, UK \\ (Correspondence should be addressed to M Korbonits; Email: m.korbonits@qmul.ac.uk)
}

\begin{abstract}
AMP-activated protein kinase (AMPK) is a key molecular player in energy homeostasis at both cellular and whole-body levels. AMPK has been shown to mediate the metabolic effects of hormones such as leptin, ghrelin, adiponectin, glucocorticoids and insulin as well as cannabinoids. Generally, activated AMPK stimulates catabolic pathways (glycolysis, fatty acid oxidation and mitochondrial biogenesis) and inhibits anabolic pathways (gluconeogenesis, glycogen, fatty acid and protein synthesis), and has a direct appetite-regulating effect in the hypothalamus. Drugs that activate AMPK, namely metformin and thiazolidinediones, are often used to treat metabolic disorders. Thus, AMPK is now recognised as a potential target for the treatment of obesity and associated co-morbidities.
\end{abstract}

Journal of Molecular Endocrinology (2010) 44, 87-97

\section{Introduction}

AMP-activated protein kinase (AMPK) has emerged as a key molecular player in energy homeostasis at both cellular and whole-body levels (Kahn et al. 2005). Initially, AMPK was shown to have lipid-related effects: it inactivates acetyl-CoA carboxylase (ACC; Carlson \& Kim 1973) and 3-hydroxy-3-methylglutaryl (HMG)-CoA reductase (Beg et al. 1973), the key regulatory enzymes of fatty acid and cholesterol synthesis. Later, the role of AMPK in carbohydrate and protein metabolism, cell cycle regulation and mitochondrial biogenesis was also described. AMPK is an evolutionarily conserved serine/ threonine kinase with a catalytic $\alpha$-subunit and regulatory $\beta$ - and $\gamma$-subunits, forming a heterotrimeric complex. The upstream regulation of AMPK is summarised in Figs 1 and 2.

\section{Role of AMPK in the central control of appetite}

AMPK is expressed throughout the brain: all isoforms are expressed in neuronal tissues including areas that are involved in the control of food intake and neuroendocrine function, such as the hypothalamus and the hindbrain (Turnley et al. 1999, Kola 2008). In the last 5 years, AMPK has emerged as a nutrient and glucose sensor in the hypothalamus (Momcilovic et al. 2006). Hypothalamic AMPK activity is increased during fasting and decreased during refeeding (Minokoshi et al. 2004). Pharmacological activation of AMPK in the rodent hypothalamus with 5-aminoimidazole-4carboxamide riboside (AICAR) causes an increase in food intake (Xue \& Kahn 2006). Alteration in ventromedial hypothalamic AMPK activity with recombinant adenoviruses expressing dominant negative (DN) or constitutively active (CA) AMPK- $\alpha 1 / \alpha 2$ subunit (Minokoshi et al. 2004) changed body weight and food intake. DN-AMPK adenovirus-treated mice ate less and had lower body weight compared with control mice. DN-AMPK mice also had decreased neuropeptide $\mathrm{Y}$ (NPY) and agouti-related peptide (AgRP) mRNA levels in the arcuate nucleus (ARC) under ad libitum fed conditions. In contrast, CA-AMPK adenovirustreated mice ate significantly more and had higher body weight with increased expression of NPY and AgRP mRNA in ARC, as well as increased orexigenic melanin-concentrating hormone expression in lateral hypothalamus. This suggests that high AMPK activity enhances orexigenic signals, whereas low AMPK activity suppresses these signals under ad libitum fed conditions. In agreement with this, deletion of AMPK $\alpha 2$ in AgRP neurons led to the development of an age-dependent lean phenotype.

Peripheral hormones from the gastrointestinal tract (peptide YY, ghrelin, cholecystokinin, glucagon-like peptide 1 (GLP-1) and oxyntomodulin) and adipose tissue (leptin, resistin and adiponectin) are important in influencing the activity of the appetite-regulating 


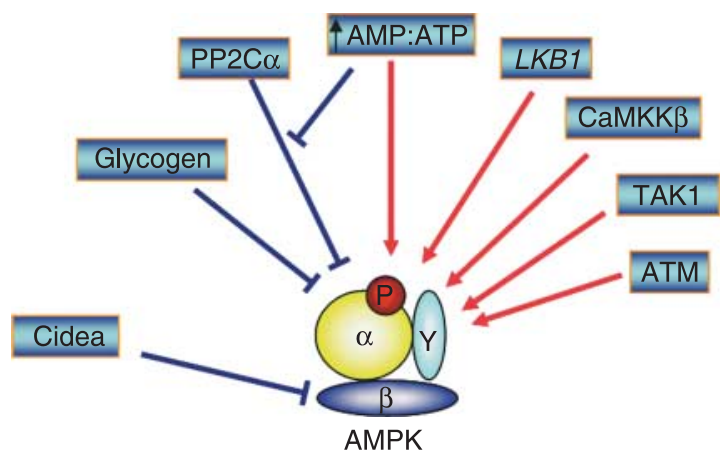

Figure 1 AMPK regulation: AMPK's upstream kinases phosphorylate the Thr172 residue of the $\alpha$-kinase subunit. LKB1, a tumour-suppressor gene (Hawley et al. 2003, Woods et al. 2003, Shaw et al. 2004), calmodulin kinase kinase (CaMKK; Hawley et al. 2005, Hurley et al. 2005, Woods et al. 2005), and the recently described kinases transforming growth factor- $\beta$-activated kinase (TAK1) and ataxia telangiectasia mutated (ATM) are the known AMPK kinases. CaMKK2 (also known as CaMKK $\beta$ ) is expressed primarily in the brain, suggesting that this $\mathrm{Ca}^{2+}$ mediated pathway may be operating in neurons (Towler \& Hardie 2007). TAK1 is a member of the mitogen-activated protein kinase kinase kinase family and is reported to phosphorylate AMPK in HeLa cells, which lack LKB1 expression (Momcilovic et al. 2006). ATM, which stimulates mitochondrial biogenesis in response to double-stranded DNA breaks, also can phosphorylate AMPK (Fu et al. 2008). A rise in AMP:ATP ratio activates AMPK i) allosterically and ii) by inhibition of dephosphorylation by protein phosphatases (Hardie et al. 1999, Sanders et al. 2007). Recently, it has been shown that AMPK can be regulated directly by glycogen and may act as a glycogen sensor (McBride et al. 2009). The $\alpha 1-6$ linkage-branched forms of glycogen allosterically inhibit AMPK more potently than the linear $\alpha 1-4$-linked forms (Carling 2009, McBride et al. 2009). In addition to the allosteric effect, the branched glycogen also inhibits LKB1- or CaMKK2-induced Thr172 phosphorylation, while dephosphorylation is not affected by glycogen. A new model of AMPK regulation, which is independent of AMP, has recently been identified. It is shown that cell death-inducing DFFA-like effector-a (Cidea) forms a complex with the $\beta$-subunit of AMPK, eliciting a ubiquitination-mediated degradation of AMPK (Qi et al. 2008).

neuronal populations in the hypothalamus. In addition, a number of these hormones have been shown to influence AMPK activity. In the short term, anorectic agents such as glucose, GLP-1 and oxyntomodulin decrease hypothalamic AMPK activity (Andersson et al. 2004, Minokoshi et al. 2004, Seo et al. 2008), leading to reduction in food intake during satiation, while orexigenic agents such as ghrelin lead to AMPK activation and increased food intake (Andersson et al. 2004, Kola et al. 2005). In the long term, the circulating anorectic insulin and leptin determine the energy and adiposity profile.

The hypothalamus is not the only location in the brain important for appetite regulation. Emerging data suggest that the nucleus tractus solitarius (NTS) in the hindbrain also has an important role. Fasting increases AMPK activity in the NTS and leptin inhibits it (Hayes et al. 2009a). Ghrelin is known to activate neurons in the NTS (Date et al. 2006). GLP-1 (7-36) amide, an anorectic hormone, acts both in the hypothalamus and the NTS (Goldstone et al. 2000, Seo et al. 2008, Hayes et al. 2009b).

\section{Role of AMPK in peripheral tissues}

AMPK is ubiquitously expressed and plays an important role in the peripheral metabolism of the skeletal muscle, liver, fat, myocardium and other tissues. In general, activated AMPK switches on catabolic processes that produce ATP and switches off ATPconsuming processes, thus restoring the AMP:ATP ratio.

AMPK plays a key role in regulating lipid metabolism. Activated AMPK phosphorylates and inhibits ACC1 and HMG-CoA, decreases fatty acid synthase (FAS) expression and activates malonyl-CoA carboxylase, thereby leading to a decrease in fatty acid and cholesterol synthesis (Woods et al. 2000, Kahn et al. 2005, Lopez et al. 2007). Activated AMPK stimulates fatty acid oxidation by decreasing malonyl-CoA levels through the inhibition of ACC2 (Merrill et al. 1997, Kahn et al. 2005, Lopez et al. 2007). This leads to an increase in carnitine palmitoyltransferase 1 (CPT1) activity and the subsequent activation of fatty acid oxidation (Kahn et al. 2005, Lopez et al. 2007). The decreased AMPK activity in visceral fat could enhance lipolysis as well as lipogenesis, although the effect on lipogenesis prevails (Divertie et al. 1991, Djurhuus et al. 2002). AMPK thus plays a key role in regulating lipid metabolism. AMPK has been suggested to inhibit catecholamine-stimulated lipolysis in adipocytes (Corton et al. 1995, Daval et al. 2005), thus lowering the plasma level of fatty acids. Activated AMPK also stimulates and upregulates the expression of peroxisome proliferator-activated receptor- $\gamma$ coactivator- $1 \alpha$, which consequently increases mitochondrial biogenesis (Terada et al. 2002, Zong et al. 2002).

AMPK also regulates glucose homeostasis. Activation of AMPK by contraction in fast-twitching muscles increases hexokinase II expression (Holmes et al. 1999), and enhances glucose uptake through the translocation of glucose transporter 4 (GLUT4) to the cell membrane and the upregulation of Glut4 gene expression (Holmes et al. 1999, Derave et al. 2000, Wright et al. 2005). Interestingly, these effects were not observed in slow-twitching soleus muscle (Derave et al. 2000, Wright et al. 2005).

AMPK regulates hepatic gluconeogenesis by inhibiting the transcription of phosphoenolpyruvate carboxykinase (PEPCK) and glucose-6-phosphatase (G6Pase; Lochhead et al. 2000, Cool et al. 2006). AMPK $\alpha 2-k n o c k o u t ~(K O)$ and LKB1-KO mice were shown to have glucose intolerance and fasting-induced hyperglycaemia, possibly caused by increased 


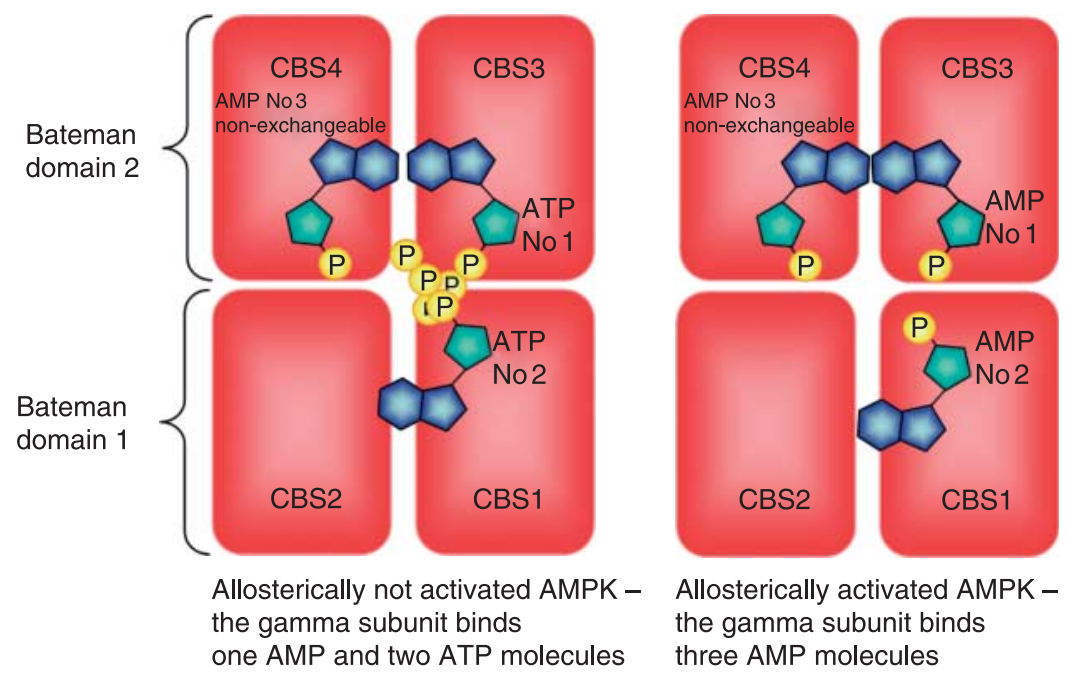

Figure 2 The $\gamma$-subunit of AMPK contains three AMP-binding sites. These are formed in the interface of its two pairs of CBS domains, also called Bateman domains. Two of these binding sites can bind either AMP or ATP, whereas a third site contains a tightly bound AMP that does not exchange (Xiao et al. 2007). When AMPK is inactive under physiological conditions, it binds two ATP and one AMP molecule, while in low energy states it binds three AMP molecules. It is now proposed that the interaction of the catalytically active kinase domain with the AMP-bound $\gamma$-subunit protects the phosphorylated Thr172 residue from dephosphorylation.

gluconeogenesis associated with increased PEPCK and G6Pase activity (Lochhead et al. 2000, Cool et al. 2006). Activated AMPK in skeletal muscle phosphorylates and inhibits glycogen synthase, thereby leading to a decrease in glycogen synthesis (Wojtaszewski et al. 2002).

Hypothalamic AMPK has been linked to the regulation of peripheral metabolism, suggesting that AMPK is a key enzyme in coordinating the interaction between peripheral and central energy regulation. Central AICAR treatment has been shown to increase both insulin-mediated and non-insulin-mediated glycogen synthesis (Perrin et al. 2004), thus implicating the role of hypothalamic AMPK in regulating muscle glycogen synthesis. Central insulin infusion also increased muscle glycogen synthesis and this effect was blocked by the co-administration of glucose, possibly mediated by AMPK (Perrin et al. 2004). Central adiponectin treatment leads to hypothalamic AMPK activation and decreases energy expenditure, possibly via a reduced expression of uncoupling protein-1 (UCP-1) in brown adipose tissue (Kubota et al. 2007). Central a-lipoic acid, which inhibits hypothalamic AMPK activity, increases UCP-1 expression and energy expenditure in brown adipose tissue (Kim et al. 2004b). Central ghrelin treatment, independently from the effect on food intake, has been shown to increase glucose utilisation rate of white and brown adipose tissues and counteract the effects of intracerebroventricular leptin treatment on fat weight, plasma glucose and insulin (Kim et al. 2004a, Theander-Carrillo et al. 2006).

\section{Role of AMPK as mediator of hormonal signals}

Intriguingly, several hormones have tissue-specific, often opposite, effects on AMPK activity (Fig. 3).

\section{Leptin}

Leptin increases AMPK activity in the skeletal muscle directly as well as indirectly through stimulation of the hypothalamo-sympathetic axis (Minokoshi et al. 2002). Chronic s.c. administration of leptin also increases the expression of AMPK in skeletal muscle (Steinberg et al. 2003). Leptin- or leptin receptor-deficient rodents showed a decreased AMPK activity in the liver ( $\mathrm{Yu}$ et al. 2004). In lean animals, leptin has been shown to attenuate hepatic glucose production and insulin resistance under normal conditions and to slightly increase AMPK activity (Brabant et al. 2005). However, these effects are lost in diet-induced obese rats, thereby suggesting an important physiological dysregulation of leptin effects in obese animals. Leptin inhibits triacylglycerol storage and stimulates fatty acid oxidation in the heart, and both AMPK-dependent (Lee et al. 2004) and AMPK-independent (Atkinson et al. 2002) pathways have been suggested.

Central injection of leptin into ventromedial hypothalamus (VMH) of rats has been shown to increase glucose uptake in the heart, brown adipose tissue and skeletal muscle, but not in white adipose tissue (Kamohara 


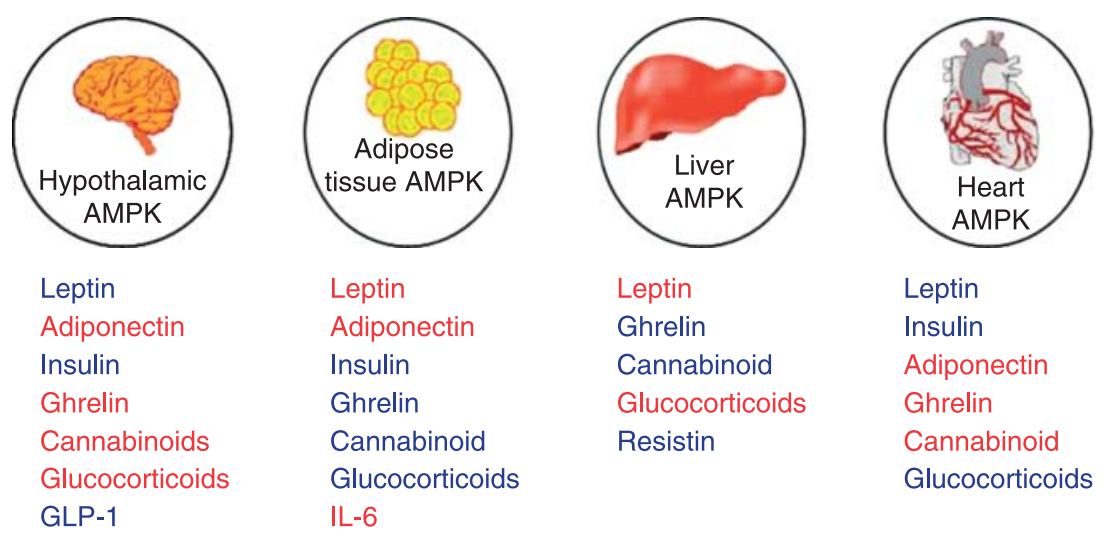

Figure 3 Hormones that activate (red) or inhibit (blue) AMPK in various tissues.

et al. 1997, Haque et al. 1999, Minokoshi et al. 1999). Central infusion of leptin decreases hepatic glycogen content (Kamohara et al. 1997, Haque et al. 1999).

In the hypothalamus, leptin has an opposite effect: it decreases AMPK activity in the ARC and paraventricular (PVC) nuclei (Minokoshi et al. 2002, 2004, Andersson et al. 2004, Mountjoy et al. 2007). By reducing the appetite centrally and increasing the peripheral fatty acid consumption, these tissue-specific effects of leptin lead to an overall negative energy balance and reduction in body weight.

\section{Adiponectin}

Adiponectin activates and stimulates liver and muscle AMPK activity in vivo and in vitro, leading to stimulation of glucose uptake, fatty acid oxidation and PEPCK (Yamauchi et al. 2002). These lead to an improvement in insulin sensitivity. Globular adiponectin was also shown to activate AMPK in primary rat adipocytes (Tomas et al. 2002, Yamauchi et al. 2002, Wu et al. 2003, Huypens et al. 2005).

Adiponectin protects the heart from ischaemic injury via AMPK- and cyclooxgenase-2-dependent mechanisms (Shibata et al. 2005). Adiponectin is also suggested to play a beneficial role in cardiac remodelling through multiple mechanisms, one of which is possibly via the activation of AMPK (Liao et al. 2005, Shibata et al. 2005). Impaired regulation of AMPK and glucose metabolism in adiponectin-deficient mice result in the development of heart failure (Liao et al. 2005). In endothelial cells, adiponectin stimulates nitric oxide production via AMPK activation, leading to beneficial vasoprotective effects (Chen et al. 2003).

It has been suggested that adiponectin may be involved in the stimulation of food intake (Kadowaki et al. 2008). Serum and cerebrospinal fluid (CSF) adiponectin concentrations increase under fasting conditions, as does expression of adiponectin receptor-1 in ARC. Central adiponectin administration leads to increased phosphorylation of AMPK and ACC in the hypothalamus (Carling 2005, Xue \& Kahn 2006, Kadowaki et al. 2008). Adiponectin KO mice were shown to have reduced food intake and decreased AMPK activity in ARC (Kadowaki et al. 2008). Thus, unlike leptin, adiponectin stimulates both central and peripheral AMPK activity. Adiponectin-transgenic ob/ob mice, which have serum adiponectin levels two- to threefold higher than ob/ob mice, have significantly higher body weight, but an improved metabolic state compared with ob/ob mice (Kim et al. 2007). Adiponectin is considered a starvation hormone: under fasting conditions, high adiponectin levels stimulate central and peripheral AMPK leading to increased food intake and decreased energy expenditure, promoting fat storage. After refeeding, adiponectin levels would fall with a consequent decrease in AMPK activity leading to reduced food intake and an increase in energy expenditure.

\section{Resistin}

Resistin is an adipokine secreted in rodents and humans, which generally seems to have opposite effects to those of adiponectin. Resistin induces insulin resistance and stimulates hepatic glucose production. These effects are thought to be mediated by a reduction in liver AMPK activity (Banerjee $e t a l$. 2004, Muse $e t$ al. 2004). It has been shown to decrease fatty acid uptake and oxidation in skeletal muscle via a reduction in the membrane content of fatty acid translocase/CD36, possibly mediated by inhibition of AMPK (Palanivel \& Sweeney 2005). Resistin, despite its anorectic effect, has been shown to phosphorylate hypothalamic AMPK and ACC. The consequent inactivation of ACC, after AMPK activation, might represent a physiological compensatory mechanism that prevents deleteriously high levels of malonyl-CoA occurring in the hypothalamus after resistin-induced FAS inhibition in the VMH (Vazquez et al. 2008). Time course-dependent resistin treatments would probably be needed to clarify this issue. 


\section{Ghrelin and cannabinoids}

Ghrelin has been shown to regulate AMPK activity in hypothalamus and peripheral tissues (Andersson et al. 2004, Kola et al. 2005). Cannabinoids are known to regulate appetite and peripheral metabolism, and AMPK has been shown to mediate these effects (Kola et al. 2005, 2008). Both ghrelin and cannabinoids have similar effects on AMPK activity in various tissues: they stimulate hypothalamic and heart AMPK activity, while inhibit adipose tissue and liver AMPK activity (Kola et al. 2005, 2008).

The mechanism of central effect of ghrelin includes the activation of $\mathrm{Ca}^{2+}$ signalling in NPY neurons in the ARC (Kohno et al. 2003, 2008). The $\mathrm{Ca}^{2+}$ rise leads to CAMKK2 activation, which can stimulate hypothalamic AMPK (Anderson et al. 2008, Sleeman \& Latres 2008). AMPK activation leads to inhibition of malonyl-CoA and stimulation of CPT1, leading to increased mitochondrial oxidation and activation of the UCP-2, which can increase NPY/AgRP neuronal activity and ultimately stimulate appetite (Andrews et al. 2008, Lopez et al. 2008).

Endocannabinoids are synthesised locally on demand, and the level in the hypothalamus varies in response to feeding and fasting (Kirkham et al. 2002). The variation in hypothalamic endocannabinoid levels seems to play an important role in mediating the anorectic effects of leptin (Di Marzo et al. 2001) and the orexigenic effects of ghrelin (Kola et al. 2008). Recently, we have shown that the effects of ghrelin on hypothalamic AMPK activity and appetite are abolished in the absence of cannabinoid type 1 receptor $(\mathrm{CB} 1)$ or in the presence of a $\mathrm{CB} 1$ antagonist rimonabant (Kola et al. 2008). These data suggest that an intact cannabinoid-signalling pathway is required for the effects of ghrelin on AMPK activity and appetite. Interestingly, i.p. injection of cannabinoids in rats results in increased plasma ghrelin levels (Zbucki et al. 2008). This suggests that the stimulation of appetite by cannabinoids may be connected to an increase in ghrelin secretion from the gastric X/A-like cells (Zbucki et al. 2008). Further studies are needed to elucidate the details of the ghrelin-cannabinoid interaction.

\section{Insulin}

Insulin has a range of metabolic effects in addition to its main role of stimulating glucose uptake into the cells. Centrally, insulin is an anorectic hormone, which has been shown to inhibit hypothalamic AMPK activity (Minokoshi et al. 2004). Insulin deficiency has been proposed as one of the factors causing hypothalamic AMPK activation and the subsequent increase in food intake seen in streptozotocin-induced diabetic rats (Namkoong et al. 2005). In the periphery, insulin inhibits AMPK in fat by activating protein kinase B/Akt complex, which can phosphorylate alphaAMPK at Ser485/491, thus leading to reduced phosphorylation at Thr172 (Kovacic et al. 2003, Horman et al. 2006). Insulin inhibits myocardial AMPK activity during ischaemic events alone or when co-administered with glucose, suggesting that the inhibitory effect of insulin on myocardial AMPK activity might be caused by enhanced glucose metabolism (Russell et al. 2004).

Insulin resistance is characterised by the inability of insulin to increase glucose uptake and repress glucose production in the liver, and it often leads to hyperglycaemia. The role of AMPK in this condition has to be considered. While activated AMPK stimulates catabolic pathways and inhibits the energy-consuming anabolic processes, insulin promotes glycogen, lipid and protein synthesis. However, both upregulate glucose uptake in muscle via an effect of GLUT1 or GLUT4 translocation and increase in GLUT4 transcription (Zheng et al. 2001, Barnes et al. 2002). In skeletal muscle, the two pathways also phosphorylate the protein AS160, which has a Rab GTPase-activating protein domain that can increase translocation of GLUT4 to the plasma membrane (Kurth-Kraczek et al. 1999, Kramer et al. 2006, Treebak et al. 2006). These factors will lead to an increase in glucose uptake, which is an important homeostatic feature of plasma glucose regulation. Furthermore, AMPK activation is thought to upregulate insulin receptor substrate-1 (Harrington et al. 2004, Shah et al. 2004, Um et al. 2004) through inhibition of the insulinmammalian target of rapamycin (mTOR) pathway (Fisher et al. 2002, Inoki et al. 2003). This will improve the insulin sensitivity profile. Both insulin and activated AMPK repress the expression of the gluconeogenic enzymes PEPCK and G6Pase (Lochhead et al. 2000). Phosphorylation of AMPK is thought to result in translocation of the transcriptional coactivator TORC2 to the cytoplasm (Koo et al. 2005), thus repressing the expression of the TORC2-target enzymes

\section{Glucagon-like peptide-1}

GLP-1 is produced from pre-proglucagon mRNA, which is expressed in NTS cell bodies in the brainstem, with projections to the PVN and other hypothalamic nuclei involved in the control of feeding (Goldstone et al. 2000). Central nervous system GLP-1 is an endogenous inhibitor of feeding acting via the GLP-1 receptor. Hypothalamic GLP-1 peptide content is decreased during fasting. Fasting-induced increase in hypothalamic AMPK activity is inhibited by GLP-1 and this could be the mechanism of its anorectic effects (Seo et al. 2008). It has been shown that the anorectic effects of leptin are at least partly via GLP-1. GLP-1 acts in both the hypothalamus and the NTS, as GLP-1 receptors located in the NTS are also suggested to regulate food intake (Hayes et al. 2009b). 


\section{Glucocorticoids}

Glucocorticoids increase appetite and lead to increased availability of metabolic fuels such as amino acids and fatty acids. Chronic or excessive exposure to glucocorticoids will result in insulin resistance, truncal obesity, hyperlipidaemia and symptoms similar to the metabolic syndrome. We have suggested that AMPK is involved in the central and peripheral effects of glucocorticoids. Glucocorticoids activate hypothalamic AMPK activity in vivo (Christ-Crain et al. 2008) either directly or via stimulation of endocannabinoid synthesis (Di et al. 2005, Christ-Crain et al. 2008), and these effects could lead to appetite stimulation (Tataranni et al. 1996). In the periphery, glucocorticoids inhibit AMPK activity in adipose tissue, leading to increased lipogenesis and fat storage (Christ-Crain et al. 2008). Glucocorticoids also inhibited AMPK activity in the heart, which might, at least in part, mediate the detrimental effects of glucocorticoid excess on the heart. Surprisingly, and somewhat unexpectedly, glucocorticoids were shown to stimulate AMPK activity in rat liver in vivo as well as in a liver cell line (Viana et al. 2006, Christ-Crain et al. 2008). This could be the result of the balance of local lipolysis, lipid oxidation and the flux of fatty acids into the liver (Foretz et al. 2005). It has been shown that an increase in free fatty acids leads to fatty acid esterification, an energy-demanding process, and this can increase the cellular AMP:ATP ratio and therefore AMPK activity (Gauthier et al. 2008).

\section{Inflammatory mediators and AMPK}

Interleukin-6 (IL-6) treatment was shown to increase AMPK phosphorylation in cultured rodent myocytes and adipocytes, as well as in muscle, liver and adipose tissue in vivo (Keller et al. 2001, Park et al. 2002, Kahn et al. 2005). Moreover, IL-6-KO mice have decreased AMPK activity in muscle (Kelly et al. 2004). Conversely, adiponectin was shown to increase IL-6 production in human synovial fibroblasts partly via AMPK regulation (Tang et al. 2007). Exercise increases AMPK activity in skeletal muscle primarily in response to changes in the AMP:ATP ratio (Ruderman et al. 2006). Exercise affects AMPK activity in fat and liver tissue (Takekoshi et al. 2006) possibly due to an increase in circulating levels of IL-6 (Keller et al. 2001). Furthermore, AMPK activity is often still increased after exercise at times when the energy state of the muscle is presumably no longer altered, and IL-6 is suggested to be involved in AMPK activation during this 'late-phase' stage (Ruderman et al. 2006).

Ciliary neurotrophic factor (CNTF) is a cytokine, which was found to induce severe anorectic effect (Miller et al. 1996), possibly via hypothalamic neurogenesis that leads to sustained reduction in caloric intake and prolonged maintenance of weight loss (Kokoeva et al. 2005). CNTF was shown to activate AMPK through the CNTFR $\alpha$-IL-6R-gp130 $\beta$ receptor complex and ultimately increasing fatty acid oxidation and reducing insulin resistance in skeletal muscle (Steinberg et al. $2006 b$ ). CNTF can also suppress inflammatory signalling cascades associated with lipid accumulation in the liver and skeletal muscle (Febbraio 2007).

The ischaemic heart releases macrophage inhibitory factor (MIF), an upstream regulator of inflammation. MIF stimulates AMPK through CD74 during ischaemia, and shows impaired ischaemic AMPK signalling in the heart of mice with germline deletion of the MIF gene (Miller et al. 2008). MIF promotes glucose uptake and protects the heart during ischaemia-reperfusion injury (Miller et al. 2008). Human fibroblasts with a low-activity MIF promoter polymorphism also have diminished MIF release and AMPK activation during hypoxia, thus linking inflammation with metabolism in the heart (Miller et al. 2008).

Tumour necrosis factor $\alpha(\mathrm{TNF} \alpha)$ signalling via TNFreceptor has been shown to suppress skeletal muscle AMPK activity both in vivo and in vitro (Steinberg et al. $2006 a)$. This happens via upregulation of protein phosphatase 2C transcription, which in turn reduces ACC phosphorylation and fatty acid oxidation as well as increasing diacylglycerol accumulation in the muscle. Suppressive effects of TNF $\alpha$ on AMPK activity, seen in obese mice with pathologically elevated levels of TNF $\alpha$, could be reversed in null mice for both TNF receptor-1 and -2 or following treatment with a TNF $\alpha$-neutralising antibody (Steinberg et al. 2006a). This indicates that AMPK is an important target for $\mathrm{TNF} \alpha$ signalling.

\section{Metabolic syndrome and AMPK}

The metabolic abnormalities observed in metabolic syndrome are insulin resistance, hypertriglyceridaemia, abdominal obesity, hypertension, reduced levels of the beneficial high-density lipoprotein and disturbances in glucose metabolism (Trevisan et al. 1998). Patients with metabolic syndrome have higher risks of developing cardiovascular disease (Isomaa et al. 2001) and have higher rates of mortality from all causes (Trevisan et al. 1998). Downstream targets of AMPK such as genes regulating carbohydrate metabolism (e.g. glycogen synthetase, ChREBP) or lipid metabolism (e.g. HMGCoA, FAS, ACC, SREBP1) play an important role in features of the metabolic syndrome. Therefore, AMPK emerged as a target for treatment of the metabolic syndrome. Two major anti-diabetic drugs that exert effects via the AMPK pathway will be considered in this review: metformin and rosiglitazone. 


\section{Metformin}

Metformin, a biguanide agent, is widely used as an antidiabetic drug. The biguanide class of anti-diabetic drugs originates from the French lilac (Galega officinalis) plant, known for several centuries to reduce the symptoms of diabetes mellitus (Witters 2001). These were first introduced in 1957 and marketed in France in 1979.

Metformin is shown to stimulate AMPK in the liver and in the muscle (Zhou et al. 2001, Zang et al. 2004, Shaw et al. 2005). This consequently stimulates glucose uptake in the muscle, induces hepatic fatty acid oxidation and inhibits hepatic glucose production and expression of lipogenic enzymes. Metformin does not activate AMPK directly, but indirectly via inhibition of complex I of the respiratory chain and the consequent increase in AMP:ATP ratio. LKB1 has also been reported to mediate the activation of AMPK in the liver by metformin (Zhou et al. 2001, Zang et al. 2004, Shaw et al. 2005).

In contrast, metformin inhibits AMPK in the hypothalamus (Chau-Van et al. 2007). Metformin inhibits low glucose-induced AMPK phosphorylation and NPY mRNA expression. These may explain the anorectic effects of metformin.

Metformin is shown to reduce mitochondrial ATP synthesis in the pancreatic $\beta$-cell, resulting in impaired glucose responsiveness, inhibition of insulin release and possibly apoptosis (Kefas et al. 2004, Leclerc et al. 2004). These findings of metformin are clearly undesired and further studies are needed to reassess the long-term effects of metformin on $\beta$-cells.

\section{Rosiglitazone}

Rosiglitazone belongs to a class of anti-diabetic drugs known as thiazolidinediones (TZDs). TZDs are used to reverse insulin resistance and improve glucose tolerance. It is known that TZDs improve insulin sensitivity by activating nuclear PPAR- $\gamma$ and the consequent regulation of gene transcription. However, it is also believed that TZDs can improve insulin sensitivity via PPAR- $\gamma$-independent mechanisms, one of which is AMPK activation (Kahn et al. 2005).

Rosiglitazone was shown to increase AMPK activity in muscle cell lines (Fryer et al. 2002), and chronic rosiglitazone treatment was reported to restore skeletal muscle AMPK $\alpha 2$ activity in obese, insulin-resistant Zucker rats (Lessard et al. 2006). Rosiglitazone activates AMPK indirectly by inhibiting complex I of the respiratory chain, which consequently leads to an increase in cellular AMP:ATP ratio (El-Mir et al. 2000, Owen et al. 2000, Brunmair et al. 2004).

TZDs also decrease the levels of resistin and stimulate release of adiponectin via action on PPAR- $\gamma$ in adipocytes (Samaha et al. 2006). These effects might also contribute to the stimulatory effect of TZDs on AMPK.

\section{Conclusion}

AMPK is one of the key regulators in energy homeostasis and is known to mediate the effects of several metabolic hormones. AMPK is now recognised as a potential target for the treatment of obesity and the metabolic syndrome.

\section{Declaration of interest}

The authors have nothing to declare.

\section{Funding}

C T Lim was supported by a Wellcome Trust Summer Studentship, and B Kola and M Korbonits are supported by a Wellcome Trust Research Grant.

\section{Acknowledgements}

We are very grateful to Dr Steve Gamblin (MRC, London) for the helpful comments on the structural description of AMPK activation.

\section{References}

Anderson KA, Ribar TJ, Lin F, Noeldner PK, Green MF, Muehlbauer MJ, Witters LA, Kemp BE \& Means AR 2008 Hypothalamic CaMKK2 contributes to the regulation of energy balance. Cell Metabolism 7 377-388.

Andersson U, Filipsson K, Abbott CR, Woods A, Smith K, Bloom SR, Carling D \& Small CJ 2004 AMP-activated protein kinase plays a role in the control of food intake. Journal of Biological Chemistry $\mathbf{2 7 9}$ 12005-12008.

Andrews ZB, Liu ZW, Walllingford N, Erion DM, Borok E, Friedman JM, Tschop MH, Shanabrough M, Cline G, Shulman GI et al. 2008 UCP-2 mediates ghrelin's action on NPY/AgRP neurons by lowering free radicals. Nature $\mathbf{4 5 4} 846-851$.

Atkinson LL, Fischer MA \& Lopaschuk GD 2002 Leptin activates cardiac fatty acid oxidation independent of changes in the AMP-activated protein kinase-acetyl-CoA carboxylase-malonyl-CoA axis. Journal of Biological Chemistry 277 29424-29430.

Banerjee RR, Rangwala SM, Shapiro JS, Rich AS, Rhoades B, Qi Y, Wang J, Rajala MW, Pocai A, Scherer PE et al. 2004 Regulation of fasted blood glucose by resistin. Science 303 1195-1198.

Barnes K, Ingram JC, Porras OH, Barros LF, Hudson ER, Fryer LG, Foufelle F, Carling D, Hardie DG \& Baldwin SA 2002 Activation of GLUT1 by metabolic and osmotic stress: potential involvement of AMPactivated protein kinase (AMPK). Journal of Cell Science 115 2433-2442.

Beg ZH, Allmann DW \& Gibson DM 1973 Modulation of 3-hydroxy-3methylglutaryl coenzyme A reductase activity with cAMP and wth protein fractions of rat liver cytosol. Biochemical and Biophysical Research Communications 54 1362-1369.

Brabant G, Muller G, Horn R, Anderwald C, Roden M \& Nave H 2005 Hepatic leptin signaling in obesity. FASEB Journal 19 1048-1050.

Brunmair B, Staniek K, Gras F, Scharf N, Althaym A, Clara R, Roden M, Gnaiger E, Nohl H, Waldhausl W et al. 2004 Thiazolidinediones, like metformin, inhibit respiratory complex I: a common mechanism contributing to their antidiabetic actions? Diabetes 53 1052-1059.

Carling D 2005 AMP-activated protein kinase: balancing the scales. Biochimie 87 87-91.

Carling D 2009 Branching out on AMPK regulation. Cell Metabolism $97-8$. 
Carlson CA \& Kim KH 1973 Regulation of hepatic acetyl coenzyme A carboxylase by phosphorylation and dephosphorylation. Journal of Biological Chemistry 248 378-380.

Chau-Van C, Gamba M, Salvi R, Gaillard RC \& Pralong FP 2007 Metformin inhibits adenosine 5 '-monophosphate-activated kinase activation and prevents increases in neuropeptide Y expression in cultured hypothalamic neurons. Endocrinology 148 507-511.

Chen H, Montagnani M, Funahashi T, Shimomura I \& Quon MJ 2003 Adiponectin stimulates production of nitric oxide in vascular endothelial cells. Journal of Biological Chemistry 278 45021-45026.

Christ-Crain M, Kola B, Lolli F, Fekete C, Seboek D, Wittmann G, Feltrin D, Igreja SC, Ajodha S, Harvey-White J et al. 2008 AMPactivated protein kinase mediates glucocorticoid-induced metabolic changes: a novel mechanism in Cushing's syndrome. FASEB Journal 22 1672-1683.

Cool B, Zinker B, Chiou W, Kifle L, Cao N, Perham M, Dickinson R, Adler A, Gagne G, Iyengar R et al. 2006 Identification and characterization of a small molecule AMPK activator that treats key components of type 2 diabetes and the metabolic syndrome. Cell Metabolism 3 403-416.

Corton JM, Gillespie JG, Hawley SA \& Hardie DG 1995 5Aminoimidazole-4-carboxamide ribonucleoside. A specific method for activating AMP-activated protein kinase in intact cells? European Journal of Biochemistry 229 558-565.

Date Y, Shimbara T, Koda S, Toshinai K, Ida T, Murakami N, Miyazato M, Kokame K, Ishizuka Y, Ishida Y et al. 2006 Peripheral ghrelin transmits orexigenic signals through the noradrenergic pathway from the hindbrain to the hypothalamus. Cell Metabolism 4 323-331.

Daval M, Diot-Dupuy F, Bazin R, Hainault I, Viollet B, Vaulont S, Hajduch E, Ferre P \& Foufelle F 2005 Anti-lipolytic action of AMPactivated protein kinase in rodent adipocytes. Journal of Biological Chemistry 280 25250-25257.

Derave W, Ai H, Ihlemann J, Witters LA, Kristiansen S, Richter EA \& Ploug T 2000 Dissociation of AMP-activated protein kinase activation and glucose transport in contracting slow-twitch muscle. Diabetes 49 1281-1287.

Di Marzo V, Goparaju SK, Wang L, Liu J, Batkai S, Jarai Z, Fezza F, Miura GI, Palmiter RD, Sugiura T et al. 2001 Leptin-regulated endocannabinoids are involved in maintaining food intake. Nature 410 822-825.

Di S, Malcher-Lopes R, Marcheselli VL, Bazan NG \& Tasker JG 2005 Rapid glucocorticoid-mediated endocannabinoid release and opposing regulation of glutamate and gamma-aminobutyric acid inputs to hypothalamic magnocellular neurons. Endocrinology 146 $4292-4301$.

Divertie GD, Jensen MD \& Miles JM 1991 Stimulation of lipolysis in humans by physiological hypercortisolemia. Diabetes 40 1228-1232.

Djurhuus CB, Gravholt CH, Nielsen S, Mengel A, Christiansen JS, Schmitz OE \& Moller N 2002 Effects of cortisol on lipolysis and regional interstitial glycerol levels in humans. American Journal of Physiology. Endocrinology and Metabolism 283 E172-E177.

El-Mir MY, Nogueira V, Fontaine E, Averet N, Rigoulet M \& Leverve X 2000 Dimethylbiguanide inhibits cell respiration via an indirect effect targeted on the respiratory chain complex I. Journal of Biological Chemistry 275 223-228.

Febbraio MA 2007 gp130 receptor ligands as potential therapeutic targets for obesity. Journal of Clinical Investigation 117 841-849.

Fisher JS, Gao J, Han DH, Holloszy JO \& Nolte LA 2002 Activation of AMP kinase enhances sensitivity of muscle glucose transport to insulin. American Journal of Physiology. Endocrinology and Metabolism 282 E18-E23.

Foretz M, Ancellin N, Andreelli F, Saintillan Y, Grondin P, Kahn A, Thorens B, Vaulont S \& Viollet B 2005 Short-term overexpression of a constitutively active form of AMP-activated protein kinase in the liver leads to mild hypoglycemia and fatty liver. Diabetes $\mathbf{5 4}$ 1331-1339.
Fryer LG, Parbu-Patel A \& Carling D 2002 The anti-diabetic drugs rosiglitazone and metformin stimulate AMP-activated protein kinase through distinct signaling pathways. Journal of Biological Chemistry 277 25226-25232.

Fu X, Wan S, Lyu YL, Liu LF \& Qi H 2008 Etoposide induces ATMdependent mitochondrial biogenesis through AMPK activation. PLOS ONE 3 e2008.

Gauthier MS, Miyoshi H, Souza SC, Cacicedo JM, Saha AK, Greenberg AS \& Ruderman NB 2008 AMP-activated protein kinase is activated as a consequence of lipolysis in the adipocyte: potential mechanism and physiological relevance. Journal of Biological Chemistry 283 16514-16524.

Goldstone AP, Morgan I, Mercer JG, Morgan DG, Moar KM, Ghatei MA \& Bloom SR 2000 Effect of leptin on hypothalamic GLP-1 peptide and brain-stem pre-proglucagon mRNA. Biochemical and Biophysical Research Communications 269 331-335.

Haque MS, Minokoshi Y, Hamai M, Iwai M, Horiuchi M \& Shimazu T 1999 Role of the sympathetic nervous system and insulin in enhancing glucose uptake in peripheral tissues after intrahypothalamic injection of leptin in rats. Diabetes 48 1706-1712.

Hardie DG, Salt IP, Hawley SA \& Davies SP 1999 AMP-activated protein kinase: an ultrasensitive system for monitoring cellular energy charge. Biochemical Journal 338 717-722.

Harrington LS, Findlay GM, Gray A, Tolkacheva T, Wigfield S, Rebholz H, Barnett J, Leslie NR, Cheng S, Shepherd PR et al. 2004 The TSC1-2 tumor suppressor controls insulin-PI3K signaling via regulation of IRS proteins. Journal of Cell Biology 166 213-223.

Hawley SA, Boudeau J, Reid JL, Mustard KJ, Udd L, Makela TP, Alessi DR \& Hardie DG 2003 Complexes between the LKB1 tumor suppressor, STRAD alpha/beta and MO25 alpha/beta are upstream kinases in the AMP-activated protein kinase cascade. Journal of Biology 228.

Hawley SA, Pan DA, Mustard KJ, Ross L, Bain J, Edelman AM, Frenguelli BG \& Hardie DG 2005 Calmodulin-dependent protein kinase kinase-beta is an alternative upstream kinase for AMPactivated protein kinase. Cell Metabolism 2 9-19.

Hayes MR, Bradley L \& Grill HJ 2009a Endogenous hindbrain glucagon-like peptide-1 receptor activation contributes to the control of food intake by mediating gastric satiation signaling. Endocrinology 150 2654-2659.

Hayes MR, Skibicka KP, Bence KK \& Grill HJ $2009 b$ Dorsal hindbrain $5^{\prime}$-adenosine monophosphate-activated protein kinase as an intracellular mediator of energy balance. Endocrinology 150 2175-2182.

Holmes BF, Kurth-Kraczek EJ \& Winder WW 1999 Chronic activation of 5'-AMP-activated protein kinase increases GLUT-4, hexokinase, and glycogen in muscle. Journal of Applied Physiology 87 1990-1995.

Horman S, Vertommen D, Heath R, Neumann D, Mouton V, Woods A, Schlattner U, Wallimann T, Carling D, Hue L et al. 2006 Insulin antagonizes ischemia-induced Thr172 phosphorylation of AMPactivated protein kinase alpha-subunits in heart via hierarchical phosphorylation of Ser485/491. Journal of Biological Chemistry 281 5335-5340.

Hurley RL, Anderson KA, Franzone JM, Kemp BE, Means AR \& Witters LA $2005 \mathrm{The}^{2+} /$ calmodulin-dependent protein kinase kinases are AMP-activated protein kinase kinases. Journal of Biological Chemistry $28029060-29066$.

Huypens P, Moens K, Heimberg H, Ling Z, Pipeleers D \& Van de Casteele M 2005 Adiponectin-mediated stimulation of AMPactivated protein kinase (AMPK) in pancreatic beta cells. Life Sciences 77 1273-1282.

Inoki K, Zhu T \& Guan KL 2003 TSC2 mediates cellular energy response to control cell growth and survival. Cell 115 577-590.

Isomaa B, Almgren P, Tuomi T, Forsen B, Lahti K, Nissen M, Taskinen MR \& Groop L 2001 Cardiovascular morbidity and mortality associated with the metabolic syndrome. Diabetes Care 24 683-689. 
Kadowaki T, Yamauchi T \& Kubota N 2008 The physiological and pathophysiological role of adiponectin and adiponectin receptors in the peripheral tissues and CNS. FEBS Letters 582 74-80.

Kahn BB, Alquier T, Carling D \& Hardie DG 2005 AMP-activated protein kinase: ancient energy gauge provides clues to modern understanding of metabolism. Cell Metabolism 1 15-25.

Kamohara S, Burcelin R, Halaas JL, Friedman JM \& Charron MJ 1997 Acute stimulation of glucose metabolism in mice by leptin treatment. Nature 389 374-377.

Kefas BA, Cai Y, Kerckhofs K, Ling Z, Martens G, Heimberg H, Pipeleers D \& Van de Casteele M 2004 Metformin-induced stimulation of AMP-activated protein kinase in beta-cells impairs their glucose responsiveness and can lead to apoptosis. Biochemical Pharmacology 68 409-416.

Keller C, Steensberg A, Pilegaard H, Osada T, Saltin B, Pedersen BK \& Neufer PD 2001 Transcriptional activation of the IL-6 gene in human contracting skeletal muscle: influence of muscle glycogen content. FASEB Journal 15 2748-2750.

Kelly M, Keller C, Avilucea PR, Keller P, Luo Z, Xiang X, Giralt M, Hidalgo J, Saha AK, Pedersen BK et al. 2004 AMPK activity is diminished in tissues of IL-6 knockout mice: the effect of exercise. Biochemical and Biophysical Research Communications 320 449-454.

Kim MS, Namkoong C, Kim HS, Jang PG, Kim Pak YM, Katakami H, Park JY \& Lee KU 2004a Chronic central administration of ghrelin reverses the effects of leptin. International Journal of Obesity and Related Metabolic Disorders 28 1264-1271.

Kim MS, Park JY, Namkoong C, Jang PG, Ryu JW, Song HS, Yun JY, Namgoong IS, Ha J, Park IS et al. 2004b Anti-obesity effects of alpha-lipoic acid mediated by suppression of hypothalamic AMP-activated protein kinase. Nature Medicine 10 727-733.

Kim JY, van de Wall E, Laplante M, Azzara A, Trujillo ME, Hofmann SM, Schraw T, Durand JL, Li H, Li G et al. 2007 Obesity-associated improvements in metabolic profile through expansion of adipose tissue. Journal of Clinical Investigation 117 2621-2637.

Kirkham TC, Williams CM, Fezza F \& Di Marzo V 2002 Endocannabinoid levels in rat limbic forebrain and hypothalamus in relation to fasting, feeding and satiation: stimulation of eating by 2-arachidonoyl glycerol. British Journal of Pharmacology 136 550-557.

Kohno D, Gao HZ, Muroya S, Kikuyama S \& Yada T 2003 Ghrelin directly interacts with neuropeptide-Y-containing neurons in the rat arcuate nucleus: $\mathrm{Ca}^{2+}$ signaling via protein kinase $\mathrm{A}$ and $\mathrm{N}$-type channel-dependent mechanisms and cross-talk with leptin and orexin. Diabetes $\mathbf{5 2}$ 948-956.

Kohno D, Sone H, Minokoshi Y \& Yada T 2008 Ghrelin raises $\left[\mathrm{Ca}^{2+}\right]_{\mathrm{i}}$ via AMPK in hypothalamic arcuate nucleus NPY neurons. Biochemical and Biophysical Research Communications 366 388-392.

Kokoeva MV, Yin H \& Flier JS 2005 Neurogenesis in the hypothalamus of adult mice: potential role in energy balance. Science 310 679-683.

Kola B 2008 Role of AMP-activated protein kinase in the control of appetite. Journal of Neuroendocrinology 20 942-951.

Kola B, Hubina E, Tucci SA, Kirkham TC, Garcia EA, Mitchell SE, Williams LM, Hawley SA, Hardie DG, Grossman AB et al. 2005 Cannabinoids and ghrelin have both central and peripheral metabolic and cardiac effects via AMP-activated protein kinase. Journal of Biological Chemistry 280 25196-25201.

Kola B, Farkas I, Christ-Crain M, Wittmann G, Lolli F, Amin F, Harvey-White J, Liposits Z, Kunos G, Grossman AB et al. 2008 The orexigenic effect of ghrelin is mediated through central activation of the endogenous cannabinoid system. PLoS ONE 3 e1797.

Koo SH, Flechner L, Qi L, Zhang X, Screaton RA, Jeffries S, Hedrick S, $\mathrm{Xu}$ W, Boussouar F, Brindle P et al. 2005 The CREB coactivator TORC2 is a key regulator of fasting glucose metabolism. Nature $\mathbf{4 3 7}$ 1109-1111.

Kovacic S, Soltys CL, Barr AJ, Shiojima I, Walsh K \& Dyck JR 2003 Akt activity negatively regulates phosphorylation of AMP-activated protein kinase in the heart. Journal of Biological Chemistry $\mathbf{2 7 8}$ 39422-39427.
Kramer HF, Witczak CA, Fujii N, Jessen N, Taylor EB, Arnolds DE, Sakamoto K, Hirshman MF \& Goodyear LJ 2006 Distinct signals regulate AS160 phosphorylation in response to insulin, AICAR, and contraction in mouse skeletal muscle. Diabetes 55 2067-2076.

Kubota N, Yano W, Kubota T, Yamauchi T, Itoh S, Kumagai H, Kozono H, Takamoto I, Okamoto S, Shiuchi T et al. 2007 Adiponectin stimulates AMP-activated protein kinase in the hypothalamus and increases food intake. Cell Metabolism 6 55-68.

Kurth-Kraczek EJ, Hirshman MF, Goodyear LJ \& Winder WW 1999 5' AMP-activated protein kinase activation causes GLUT4 translocation in skeletal muscle. Diabetes 48 1667-1671.

Leclerc I, Woltersdorf WW, da Silva Xavier G, Rowe RL, Cross SE, Korbutt GS, Rajotte RV, Smith R \& Rutter GA 2004 Metformin, but not leptin, regulates AMP-activated protein kinase in pancreatic islets: impact on glucose-stimulated insulin secretion. American Journal of Physiology. Endocrinology and Metabolism 286 E1023-E1031.

Lee Y, Naseem RH, Duplomb L, Park BH, Garry DJ, Richardson JA, Schaffer JE \& Unger RH 2004 Hyperleptinemia prevents lipotoxic cardiomyopathy in acyl CoA synthase transgenic mice. PNAS 101 13624-13629.

Lessard SJ, Chen ZP, Watt MJ, Hashem M, Reid JJ, Febbraio MA, Kemp BE \& Hawley JA 2006 Chronic rosiglitazone treatment restores AMPK $\alpha 2$ activity in insulin-resistant rat skeletal muscle. American Journal of Physiology. Endocrinology and Metabolism 290 E251-E257.

Liao Y, Takashima S, Maeda N, Ouchi N, Komamura K, Shimomura I, Hori M, Matsuzawa Y, Funahashi T \& Kitakaze M 2005 Exacerbation of heart failure in adiponectin-deficient mice due to impaired regulation of AMPK and glucose metabolism. Cardiovascular Research 67 705-713.

Lochhead PA, Salt IP, Walker KS, Hardie DG \& Sutherland C 2000 5-Aminoimidazole-4-carboxamide riboside mimics the effects of insulin on the expression of the 2 key gluconeogenic genes PEPCK and glucose-6-phosphatase. Diabetes 49 896-903.

Lopez M, Lelliott CJ \& Vidal-Puig A 2007 Hypothalamic fatty acid metabolism: a housekeeping pathway that regulates food intake. BioEssays 29 248-261.

Lopez M, Lage R, Saha AK, Perez-Tilve D, Vazquez MJ, Varela L, Sangiao-Alvarellos S, Tovar S, Raghay K, Rodriguez-Cuenca S et al. 2008 Hypothalamic fatty acid metabolism mediates the orexigenic action of ghrelin. Cell Metabolism 7 389-399.

McBride A, Ghilagaber S, Nikolaev A \& Hardie DG 2009 The glycogenbinding domain on the AMPK beta subunit allows the kinase to act as a glycogen sensor. Cell Metabolism 9 23-34.

Merrill GF, Kurth EJ, Hardie DG \& Winder WW 1997 AICA riboside increases AMP-activated protein kinase, fatty acid oxidation, and glucose uptake in rat muscle. American Journal of Physiology $\mathbf{2 7 3}$ E1107-E1112.

Miller RG, Petajan JH, Bryan WW, Armon C, Barohn RJ, Goodpasture JC, Hoagland RJ, Parry GJ, Ross MA \& Stromatt SC 1996 A placebocontrolled trial of recombinant human ciliary neurotrophic (rhCNTF) factor in amyotrophic lateral sclerosis. rhCNTF ALS Study Group. Annals of Neurology 39 256-260.

Miller EJ, Li J, Leng L, McDonald C, Atsumi T, Bucala R \& Young LH 2008 Macrophage migration inhibitory factor stimulates AMP-activated protein kinase in the ischaemic heart. Nature 451 578-582.

Minokoshi Y, Haque MS \& Shimazu T 1999 Microinjection of leptin into the ventromedial hypothalamus increases glucose uptake in peripheral tissues in rats. Diabetes 48 287-291.

Minokoshi Y, Kim YB, Peroni OD, Fryer LG, Muller C, Carling D \& Kahn BB 2002 Leptin stimulates fatty-acid oxidation by activating AMP-activated protein kinase. Nature 415 339-343.

Minokoshi Y, Alquier T, Furukawa N, Kim YB, Lee A, Xue B, Mu J, Foufelle F, Ferre P, Birnbaum MJ et al. 2004 AMP-kinase regulates food intake by responding to hormonal and nutrient signals in the hypothalamus. Nature $\mathbf{4 2 8}$ 569-574. 
Momcilovic M, Hong SP \& Carlson M 2006 Mammalian TAK1 activates Snf1 protein kinase in yeast and phosphorylates AMP-activated protein kinase in vitro. Journal of Biological Chemistry 281 25336-25343.

Mountjoy PD, Bailey SJ \& Rutter GA 2007 Inhibition by glucose or leptin of hypothalamic neurons expressing neuropeptide $\mathrm{Y}$ requires changes in AMP-activated protein kinase activity. Diabetologia $\mathbf{5 0}$ $168-177$.

Muse ED, Obici S, Bhanot S, Monia BP, McKay RA, Rajala MW, Scherer PE \& Rossetti L 2004 Role of resistin in diet-induced hepatic insulin resistance. Journal of Clinical Investigation 114 232-239.

Namkoong C, Kim MS, Jang PG, Han SM, Park HS, Koh EH, Lee WJ, Kim JY, Park IS, Park JY et al. 2005 Enhanced hypothalamic AMP-activated protein kinase activity contributes to hyperphagia in diabetic rats. Diabetes $\mathbf{5 4} 63-68$.

Owen MR, Doran E \& Halestrap AP 2000 Evidence that metformin exerts its anti-diabetic effects through inhibition of complex 1 of the mitochondrial respiratory chain. Biochemical Journal 348 $607-614$.

Palanivel R \& Sweeney G 2005 Regulation of fatty acid uptake and metabolism in L6 skeletal muscle cells by resistin. FEBS Letters $\mathbf{5 7 9}$ 5049-5054.

Park H, Kaushik VK, Constant S, Prentki M, Przybytkowski E, Ruderman NB \& Saha AK 2002 Coordinate regulation of malonylCoA decarboxylase, sn-glycerol-3-phosphate acyltransferase, and acetyl-CoA carboxylase by AMP-activated protein kinase in rat tissues in response to exercise. Journal of Biological Chemistry 277 32571-32577.

Perrin C, Knauf C \& Burcelin R 2004 Intracerebroventricular infusion of glucose, insulin, and the adenosine monophosphate-activated kinase activator, 5-aminoimidazole-4-carboxamide-1-beta-D-ribofuranoside, controls muscle glycogen synthesis. Endocrinology 145 4025-4033.

Qi J, Gong J, Zhao T, Zhao J, Lam P, Ye J, Li JZ, Wu J, Zhou HM \& Li P 2008 Downregulation of AMP-activated protein kinase by Cideamediated ubiquitination and degradation in brown adipose tissue. EMBO Journal 27 1537-1548.

Ruderman NB, Keller C, Richard AM, Saha AK, Luo Z, Xiang X, Giralt M, Ritov VB, Menshikova EV, Kelley DE et al. 2006 Interleukin-6 regulation of AMP-activated protein kinase. Potential role in the systemic response to exercise and prevention of the metabolic syndrome. Diabetes 55 S48-S54.

Russell RR III, Li J, Coven DL, Pypaert M, Zechner C, Palmeri M, Giordano FJ, Mu J, Birnbaum MJ \& Young LH 2004 AMP-activated protein kinase mediates ischemic glucose uptake and prevents postischemic cardiac dysfunction, apoptosis, and injury. Journal of Clinical Investigation 114 495-503.

Samaha FF, Szapary PO, Iqbal N, Williams MM, Bloedon LT, Kochar A, Wolfe ML \& Rader DJ 2006 Effects of rosiglitazone on lipids, adipokines, and inflammatory markers in nondiabetic patients with low high-density lipoprotein cholesterol and metabolic syndrome. Arteriosclerosis, Thrombosis, and Vascular Biology 26 624-630.

Sanders MJ, Grondin PO, Hegarty BD, Snowden MA \& Carling D 2007 Investigating the mechanism for AMP activation of the AMPactivated protein kinase cascade. Biochemical Journal 403 139-148.

Seo S, Ju S, Chung H, Lee D \& Park S 2008 Acute effects of glucagon-like peptide-1 on hypothalamic neuropeptide and AMP activated kinase expression in fasted rats. Endocrine Journal 55 867-874.

Shah OJ, Wang Z \& Hunter T 2004 Inappropriate activation of the TSC/Rheb/mTOR/S6K cassette induces IRS1/2 depletion, insulin resistance, and cell survival deficiencies. Current Biology 14 $1650-1656$.

Shaw RJ, Kosmatka M, Bardeesy N, Hurley RL, Witters LA, DePinho RA \& Cantley LC 2004 The tumor suppressor LKB1 kinase directly activates AMP-activated kinase and regulates apoptosis in response to energy stress. PNAS 101 3329-3335.
Shaw RJ, Lamia KA, Vasquez D, Koo SH, Bardeesy N, Depinho RA, Montminy M \& Cantley LC 2005 The kinase LKB1 mediates glucose homeostasis in liver and therapeutic effects of metformin. Science 310 1642-1646.

Shibata R, Sato K, Pimentel DR, Takemura Y, Kihara S, Ohashi K, Funahashi T, Ouchi N \& Walsh K 2005 Adiponectin protects against myocardial ischemia-reperfusion injury through AMPK- and COX-2-dependent mechanisms. Nature Medicine 11 1096-1103.

Sleeman MW \& Latres E 2008 The CAMplexities of central ghrelin. Cell Metabolism 7 361-362.

Steinberg GR, Rush JW \& Dyck DJ 2003 AMPK expression and phosphorylation are increased in rodent muscle after chronic leptin treatment. American Journal of Physiology. Endocrinology and Metabolism 284 E648-E654.

Steinberg GR, Michell BJ, van Denderen BJ, Watt MJ, Carey AL, Fam BC, Andrikopoulos S, Proietto J, Gorgun CZ, Carling D et al. $2006 a$ Tumor necrosis factor alpha-induced skeletal muscle insulin resistance involves suppression of AMP-kinase signaling. Cell Metabolism 4 465-474.

Steinberg GR, Watt MJ, Fam BC, Proietto J, Andrikopoulos S, Allen AM, Febbraio MA \& Kemp BE $2006 b$ Ciliary neurotrophic factor suppresses hypothalamic AMP-kinase signaling in leptin-resistant obese mice. Endocrinology 147 3906-3914.

Takekoshi K, Fukuhara M, Quin Z, Nissato S, Isobe K, Kawakami Y \& Ohmori H 2006 Long-term exercise stimulates adenosine monophosphate-activated protein kinase activity and subunit expression in rat visceral adipose tissue and liver. Metabolism 55 1122-1128.

Tang CH, Chiu YC, Tan TW, Yang RS \& Fu WM 2007 Adiponectin enhances IL-6 production in human synovial fibroblast via an AdipoR1 receptor, AMPK, p38, and NF-kappa B pathway. Journal of Immunology 179 5483-5492.

Tataranni PA, Larson DE, Snitker S, Young JB, Flatt JP \& Ravussin E 1996 Effects of glucocorticoids on energy metabolism and food intake in humans. American Journal of Physiology 271 E317-E325.

Terada S, Goto M, Kato M, Kawanaka K, Shimokawa T \& Tabata I 2002 Effects of low-intensity prolonged exercise on PGC-1 mRNA expression in rat epitrochlearis muscle. Biochemical and Biophysical Research Communications 296 350-354.

Theander-Carrillo C, Wiedmer P, Cettour-Rose P, Nogueiras R, Perez-Tilve D, Pfluger P, Castaneda TR, Muzzin P, Schurmann A, Szanto I et al. 2006 Ghrelin action in the brain controls adipocyte metabolism. Journal of Clinical Investigation 116 1983-1993.

Tomas E, Tsao TS, Saha AK, Murrey HE, Zhang CcC, Itani SI, Lodish HF \& Ruderman NB 2002 Enhanced muscle fat oxidation and glucose transport by ACRP30 globular domain: acetyl-CoA carboxylase inhibition and AMP-activated protein kinase activation. PNAS 99 16309-16313.

Towler MC \& Hardie DG 2007 AMP-activated protein kinase in metabolic control and insulin signaling. Circulation Research 100 328-341.

Treebak JT, Glund S, Deshmukh A, Klein DK, Long YC, Jensen TE, Jorgensen SB, Viollet B, Andersson L, Neumann D et al. 2006 AMPK-mediated AS160 phosphorylation in skeletal muscle is dependent on AMPK catalytic and regulatory subunits. Diabetes $\mathbf{5 5}$ 2051-2058.

Trevisan M, Liu J, Bahsas FB \& Menotti A 1998 Syndrome X and mortality: a population-based study. Risk Factor and Life Expectancy Research Group. American Journal of Epidemiology 148 958-966.

Turnley AM, Stapleton D, Mann RJ, Witters LA, Kemp BE \& Bartlett PF 1999 Cellular distribution and developmental expression of AMP-activated protein kinase isoforms in mouse central nervous system. Journal of Neurochemistry 72 1707-1716.

Um SH, Frigerio F, Watanabe M, Picard F, Joaquin M, Sticker M, Fumagalli S, Allegrini PR, Kozma SC, Auwerx J et al. 2004 Absence of S6K1 protects against age- and diet-induced obesity while enhancing insulin sensitivity. Nature 431 200-205. 
Vazquez MJ, Gonzalez CR, Varela L, Lage R, Tovar S, SangiaoAlvarellos S, Williams LM, Vidal-Puig A, Nogueiras R, Lopez M et al. 2008 Central resistin regulates hypothalamic and peripheral lipid metabolism in a nutritional-dependent fashion. Endocrinology 149 4534-4543.

Viana AY, Sakoda H, Anai M, Fujishiro M, Ono H, Kushiyama A, Fukushima Y, Sato Y, Oshida Y, Uchijima Y et al. 2006 Role of hepatic AMPK activation in glucose metabolism and dexamethasoneinduced regulation of AMPK expression. Diabetes Research and Clinical Practice 73 135-142.

Witters LA 2001 The blooming of the French lilac. Journal of Clinical Investigation 108 1105-1107.

Wojtaszewski JF, Jorgensen SB, Hellsten Y, Hardie DG \& Richter EA 2002 Glycogen-dependent effects of 5-aminoimidazole-4-carboxamide (AICA)-riboside on AMP-activated protein kinase and glycogen synthase activities in rat skeletal muscle. Diabetes $\mathbf{5 1}$ 284-292.

Woods A, Azzout-Marniche D, Foretz M, Stein SC, Lemarchand P, Ferre P, Foufelle F \& Carling D 2000 Characterization of the role of AMP-activated protein kinase in the regulation of glucoseactivated gene expression using constitutively active and dominant negative forms of the kinase. Molecular and Cellular Biology 20 6704-6711.

Woods A, Johnstone SR, Dickerson K, Leiper FC, Fryer LG, Neumann D, Schlattner U, Wallimann T, Carlson M \& Carling D 2003 LKB1 is the upstream kinase in the AMP-activated protein kinase cascade. Current Biology 13 2004-2008.

Woods A, Dickerson K, Heath R, Hong SP, Momcilovic M, Johnstone SR, Carlson M \& Carling D $2005 \mathrm{Ca}^{2+} /$ calmodulin-dependent protein kinase kinase-beta acts upstream of AMP-activated protein kinase in mammalian cells. Cell Metabolism 2 21-33.

Wright DC, Geiger PC, Holloszy JO \& Han DH 2005 Contraction- and hypoxia-stimulated glucose transport is mediated by a $\mathrm{Ca}^{2+}$ dependent mechanism in slow-twitch rat soleus muscle. American Journal of Physiology. Endocrinology and Metabolism 288 E1062-E1066.

Wu X, Motoshima H, Mahadev K, Stalker TJ, Scalia R \& Goldstein BJ 2003 Involvement of AMP-activated protein kinase in glucose uptake stimulated by the globular domain of adiponectin in primary rat adipocytes. Diabetes 52 1355-1363.
Xiao B, Heath R, Saiu P, Leiper FC, Leone P, Jing C, Walker PA, Haire L, Eccleston JF, Davis CT et al. 2007 Structural basis for AMP binding to mammalian AMP-activated protein kinase. Nature 449 496-500.

Xue B \& Kahn BB 2006 AMPK integrates nutrient and hormonal signals to regulate food intake and energy balance through effects in the hypothalamus and peripheral tissues. Journal of Physiology 574 $73-83$.

Yamauchi T, Kamon J, MinokoshiY, Ito Y, Waki H, Uchida S, Yamashita S, Noda M, Kita S, Ueki K et al. 2002 Adiponectin stimulates glucose utilization and fatty-acid oxidation by activating AMP-activated protein kinase. Nature Medicine 8 1288-1295.

Yu X, McCorkle S, Wang M, Lee Y, Li J, Saha AK, Unger RH \& Ruderman NB 2004 Leptinomimetic effects of the AMP kinase activator AICAR in leptin-resistant rats: prevention of diabetes and ectopic lipid deposition. Diabetologia 47 2012-2021.

Zang M, Zuccollo A, Hou X, Nagata D, Walsh K, Herscovitz H, Brecher P, Ruderman NB \& Cohen RA 2004 AMP-activated protein kinase is required for the lipid-lowering effect of metformin in insulin-resistant human HepG2 cells. Journal of Biological Chemistry 279 47898-47905.

Zbucki RL, Sawicki B, Hryniewicz A \& Winnicka MM 2008 Cannabinoids enhance gastric X/A-like cells activity. Folia Histochemistry and Cytobiology 46 219-224.

Zheng D, MacLean PS, Pohnert SC, Knight JB, Olson AL, Winder WW \& Dohm GL 2001 Regulation of muscle GLUT-4 transcription by AMP-activated protein kinase. Journal of Applied Physiology 91 1073-1083.

Zhou G, Myers R, Li Y, Chen Y, Shen X, Fenyk-Melody J, Wu M, Ventre J, Doebber T, Fujii N et al. 2001 Role of AMP-activated protein kinase in mechanism of metformin action. Journal of Clinical Investigation 108 $1167-1174$

Zong H, Ren JM, Young LH, Pypaert M, Mu J, Birnbaum MJ \& Shulman GI 2002 AMP kinase is required for mitochondrial biogenesis in skeletal muscle in response to chronic energy deprivation. PNAS 99 15983-15987.

Received in final form 26 June 2009

Accepted 22 July 2009

Made available online as an Accepted Preprint 22 July 2009 